\title{
MICROPROPAGATION OF MATURE QUERCUS ILEX L. TREES BY AXILLARY BUDDING
}

\author{
Martínez MT, Corredoira E, Vieitez AM, Cernadas MJ, Montenegro R, Ballester A, Vieitez FJ, \\ San José MC*
}

Plant Cell Tissue Organ Culture (2017) 131: 499-512

Group of Biotechnology and Forestry Improvement. Department of Plant Physiology. Instituto de Investigaciones Agrobiológicas de Galicia (IIAG-CSIC). Avda. de Vigo s/n. 15705 Santiago de Compostela, Spain.

* Author for correspondence: $\underline{\text { sanjose@iiag.csic.es }}$

\begin{abstract}
This paper reports the successful micropropagation of mature Quercus ilex trees known as reluctant to in vitro propagation. Crown branch segments collected from 30 and100 year-old trees were forced in order to promote the production of sprouting shoots that were used as a source of explants for initiating the cultures. Sterilization was critical and required low-level disinfestation protocols. Six out of the eight mature genotypes attempted were successfully inoculated and then maintained in culture with varying responses. Shoot proliferation of holm oak was influenced by BA concentration, with improved multiplication and shoot appearance when the BA concentration was sequentially reduced over the culture period. Micropropagation by axillary budding was achieved by culturing shoots on a sequence of cytokinin-enriched Lloyd and McCown (WPM) media alternating 2 week-long subcultures on 0.44 $\mu \mathrm{M}$ benzyadenine (BA) first, followed by $0.22 \mu \mathrm{M}$ BA, then $0.044 \mu \mathrm{M}$ BA plus $0.46 \mu \mathrm{M}$ zeatin. Sucrose concentration and agar brand affected shoot proliferation, and the best results were obtained on WPM medium supplemented with $8 \mathrm{~g} \mathrm{~L}^{-1}$ Sigma agar (A-1296; Sigma-Aldrich) and $30 \mathrm{~g} \mathrm{~L}^{-1}$ sucrose. Addition of $20 \mu \mathrm{M}$ silver thiosulphate had a significant positive effect on the appearance and development of shoots with a higher number of shoots being healthy and showing reduced shoot tip necrosis and early senescence of leaves. The $18.8 \%$ of the microshoots obtained for one clone could be rooted within 15 days on a half-strength Murashige and Skoog medium containing $14.8 \mu \mathrm{M}$ or $24.6 \mu \mathrm{M}$ indole-3-butyric acid and $0.54 \mu \mathrm{M} \alpha$-naphthalene acetic acid.
\end{abstract}

Keywords: Holm oak; Ethylene inhibitors; Gelling agents; Rejuvenation; Rooting; Shoot culture initiation

Conflict of interest: The authors declare that they have no conflict of interest 


\section{Introduction}

The genus Quercus (family Fagaceae) is native to the northern hemisphere and includes both deciduous and evergreen species. Quercus ilex L. (holm oak) is one of the most common tree species in the Mediterranean basin, where it displays a remarkable capacity to adapt to local conditions (Ruíz de la Torre 2006). In Spain, Quercus ilex is the dominant oak species in the artificially created and maintained oak woodland systems known as dehesas. These systems are considered the archetype of sustainable agrosilvicultural practices and are included in the Special Areas of Conservation defined in EU directive 92/43 (Council of Europe, UNEP and ECNC, 1996; Liñan et al. 2011). These multipurpose woodlands, usually derived from natural forest, are used for livestock rearing, cereal cropping, cork production, mushroom and firewood harvesting, beekeeping and hunting (Moreno and Pulido 2009; Huntsinger et al. 2013). Over the last few decades dehesas and other agrosilvopastoral systems in Europe have faced serious threats to their existence (Moreno and Pulido 2009). These threats include ecological aging, a lowered capacity of the trees to regenerate and the abandonment of traditional uses (Plieninger et al. 2004). In most dehesas, adult holm oak trees that are removed or die are rarely replaced by seedlings. In addition, holm oak populations have suffered a gradual decline in recent years as a result of oak dieback (la seca), which is mainly caused by the fungus Phytophthora cinnamomi (Sánchez et al. 2002; Corcobado et al. 2013). This has led to a reduction in holm oak woodlands and a serious environmental problem that threatens the sustainability of the species.

The development of reliable protocols for in vitro propagation of holm oak would enable production demands to be satisfied, in addition to facilitating the propagation of genetically superior material produced in genetic improvement programmes. Propagation of holm oak is extremely difficult, and the species is considered recalcitrant to conventional vegetative propagation, even when young material is used. Traditional propagation by germinating seeds is difficult and the establishment of seed orchards is thus complicated (Mauri and Manzanera 2005; Liñán et al. 2011). Propagation via cuttings is greatly influenced by the age of the ortet, as the rate of rooting decreases from around $70 \%$ in cuttings from 1month-old seedlings to $\leq 20 \%$ in cuttings from 7-month-old plantlets (L'Helgoul'ch and Espagnac 1987). Each of these factors hinders the production of plant material for forest restoration and for reforestation, breeding and genetic improvement programmes.

These difficulties could potentially be overcome by the application of plant biotechnology methods, such as tissue culture, which would enable germplasm conservation, large-scale propagation of genetically improved germplasm and genetic transformation of tree species (Blasco et al. 2013). Micropropagation by axillary budding is the preferred procedure for the commercial propagation of hardwood species, as it is generally the easiest method to apply and is also considered the most suitable for ensuring the genetic stability of the regenerated plants (Bonga and von Aderkas 1992; Monteuuis et al. 2008; Gomes and Canhoto 2009). Moreover, in recent years, leaves and apices derived from in vitro shoot cultures established from adult trees of several woody species have been used to initiate somatic embryos (San José et al. 2010; Correia et al. 2011; Corredoira et al. 2012; Martínez et al. 2015; 
Corredoira et al. 2015). Propagation by axillary budding has been applied to different oak species to enable the rapid production and regeneration of trees with desired traits, thus yielding genetically superior traits without gene segregation (Vieitez et al. 2012). Unfortunately, the number of studies concerning this method of micropropagation in holm oak are limited. There is only one report of in vitro regeneration of this species from axillary buds, which is limited to material of juvenile origin (Liñán et al. 2011). As far as we know, micropropagation by axillary budding of mature $Q$. ilex trees has not yet been reported.

Mature plants must be used as sources of initial explants for clonal propagation of trees of proven value in the field. However, many woody plants can only be regenerated in vitro from zygotic embryos or young seedlings (Bonga et al. 2010; Bonga 2017). In this regard, the recalcitrance of mature material is generally considered a problem for the application of micropropagation techniques in woody plants (McCown 2000; Bonga et al. 2010; Ballester et al. 2016; Monteuuis 2016). Several factors related to the culture medium composition can affect micropropagation, especially as regards overcoming recalcitrance (Benson 2000). Plant growth regulators (PGRs), carbohydrate sources, gelling agents, basal media composition, amino acids, and ethylene inhibitors are the most widely studied of these factors (Benson 2000; George and Debergh 2008; Bonga et al. 2010). The type and concentration of cytokinins used are clearly very important for shoot/bud proliferation (Howell et al. 2003; Van Staden et al. 2008), as cytokinins penetrate the axillary bud and promote outgrowth. The cytokinin, 6benzylaminopurine (BA), is probably the most widely used cytokinin in plant micropropagation, as it is effective and affordable (Bairu et al. 2007). Other cytokinins such as zeatin and 6- $(\gamma, \gamma-$ dimethylallylamino) purine $(2 \mathrm{iP})$ are common alternatives cytokinin to $\mathrm{BA}$ for use in shoot proliferation. The composition of the nutrient medium is undoubtedly one of the most important factors in tissue culture (Ramage and Williams 2002; Poothong and Reed 2014). As the mineral requirements of different species vary widely, these must also be established. There are about a dozen formulations of various media and their modifications that can be used in the micropropagation of woody plants (Ďurkovič and Mišalová 2008; Vieitez 2012) such as MS (Murashige and Skoog 1962), WPM (Woody Plant Medium; Lloyd and McCown 1980), GD (Gresshoff and Doy 1972), or SH (Schenk and Hildebrandt 1972). In general, what changes in the different mineral formulations, is not only the presence of the mineral elements, but also their concentration and their presentation form. The main variations generally affect the amount of nitrogen, as well as the nitrate/ammonium ratio. Ethylene, a gaseous PGR produced by cultured plant tissues, causes shoot growth anomalies such as shoot apex necrosis and leaf abscission (Vieitez et al. 2009). However, these effects can be reduced by adding silver nitrate $\left(\mathrm{AgNO}_{3}\right)$ and silver thiosulphate (STS) to the culture medium, and this has proved beneficial to shoot growth and organogenesis in a number of studies (Reis et al. 2003; Burgos and Alburquerque 2003; Alaska-Kennedy et al. 2005; Qin et al. 2005; Liu and Pijut 2008; Vieitez et al. 2009; Park et al. 2016). Many studies have demonstrated the influence of type and brand of gelling agents on shoot morphology and hyperhydricity, indicating the importance of considering such effects 
(Scholten and Pierik 1998; Thorpe et al. 2008 and references therein). Carbohydrates play an important role in micropropagation as a carbon and energy source and as an osmotic agent (Thorpe et al. 2008). In tissue culture, sucrose is the most common source of carbon used, and is usually added to the medium at a concentration of $30 \mathrm{~g} \mathrm{~L}^{-1}$. However, optimization of the sucrose concentration can greatly overcome the problems associated with axillary shoot proliferation (Benson 2000).

In view of the economic, cultural and ecological importance of $Q$. ilex, combined with the lack of suitable regeneration technologies, the main objectives of this report were (1) to study the initiation and stabilization phase of axillary shoot cultures derived from mature trees, (2) to define the shoot proliferation phase by evaluating the effect of baseline mineral media, gelling agents, ethylene inhibitors, and sucrose concentration, and (3) to study the rooting phase of microshoots for holm oak regeneration.

\section{Materials and methods}

Plant material and culture conditions

The source material consisted of dormant branches from the upper crowns of the eight mature $Q$. ilex trees, growing in Quintos de Mora (Toledo, Spain) for six of them (Q Genotypes: 100 years old) and in El Encín (Madrid, Spain) for the two remaining (E genotypes: 30 years old).The branches were collected in January 2013 (genotypes Q) and in January 2014 (genotypes E), and were cut from the proximal part in $25-30 \mathrm{~cm}$ in length. Branch segments $(2-4 \mathrm{~cm}$ in diameter for genotypes $\mathrm{Q}$, and $1-2 \mathrm{~cm}$ or $2-5 \mathrm{~cm}$ in diameter for genotypes $\mathrm{E}$ ) were surface sterilised by immersion in a fungicidal solution (3.5 $\mathrm{g} \mathrm{L}^{-1}$; Cuprosan WG, Bayer, Germany) for $1 \mathrm{~h}$. Segments were subsequently inserted upright in moistened perlite and placed in a growth chamber at $25^{\circ} \mathrm{C}$ and $80-90 \%$ relative humidity under a $16-\mathrm{h}$ photoperiod (90-100 $\mu \mathrm{mol} \mathrm{m} \mathrm{m}^{-2} \mathrm{~s}^{-1}$ provided by cool-white fluorescent lamps) to promote the development of axillary or epicormics shoots, which appeared after approximately 3-4 weeks. The sprouting shoots were used as the source of primary explants for in vitro culture establishment (Fig. 1A). The flushing capacity of each genotype was evaluated by recording the number and length of all sprouting shoots, which were then cut off, defoliated and surface-disinfected by immersion for 6 min in a $0.3 \%(\mathrm{v} / \mathrm{v})$ solution of free chlorine (chlorine tablets; Millipore ${ }^{\circledR}$, Merck, USA) containing two to three drops of Tween $80^{\circledR}$. The treated shoots were then rinsed three times in sterile water for $10 \mathrm{~min}$. Explants consisting of 0.5 to $1 \mathrm{~cm}$ long shoot tips and nodal segments (with one or two nodes) trimmed from the disinfected shoots were used as primary explants. The explants (one explant per tube) were inserted upright in the culture tubes $(30 \times 150 \mathrm{~mm})$. Each tube contained $16 \mathrm{ml}$ of WPM supplemented with $2.2 \mu \mathrm{M} \mathrm{BA}, 80 \mathrm{mg} \mathrm{L}^{-1}$ ascorbic acid, $30 \mathrm{~g} \mathrm{~L}^{-1}$ sucrose, and $7 \mathrm{~g} \mathrm{~L}^{-1}$ Vitro agar (Pronadisa, Spain). The medium was adjusted to $\mathrm{pH} 5.7$ before being autoclaved at $115^{\circ} \mathrm{C}$ for $20 \mathrm{~min}$. The ascorbic acid was filter sterilised and added to the autoclaved medium. All cultures were maintained in a growth chamber with a $16-\mathrm{h}$ photoperiod $\left(50-60 \mu \mathrm{mol} \mathrm{m} \mathrm{m}^{-2} \mathrm{~s}^{-1}\right.$ provided by cool-white fluorescent lamps at $25^{\circ} \mathrm{C}$ 
(light) and $20^{\circ} \mathrm{C}$ (dark) (standard conditions). After primary culture for $24 \mathrm{~h}$, each explant was moved within the same tube to an area free of excreted phenolic compounds to prevent contact with such compounds. The explants were subcultured every 2 weeks on the same medium, for 8 weeks, and the concentration of BA was then decreased to $0.89 \mu \mathrm{M}$ for the last 2 weeks of subculture. At the end of the 8-week culture period, the numbers of contaminated explants, explants with opening buds per initial explants inoculated (response rate), the percentage of explants with shoots $<0.5 \mathrm{~cm}$ and with shoots $\geq 0.5 \mathrm{~cm}$ in lengthper responsive explant, and stabilization period were recorded. Cultures were considered stabilized when in vitro shoot growth was uniform and continuous (McCown 2000).

Shoot multiplication experiments

New shoots longer than $0.5 \mathrm{~cm}$ were excised from the original explants and cultured vertically in 500$\mathrm{ml}$ glass jars (11 x $11 \mathrm{~cm}$; Luminarc, France) containing $70 \mathrm{ml}$ of multiplication medium. On the basis of our experience with other Quercus spp. (San José et al. 1990; Vieitez et al. 2009) and other woody species, the multiplication medium consisted of WPM nutrients supplemented with $30 \mathrm{~g} \mathrm{~L}^{-1}$ sucrose, $8 \mathrm{~g}$ $\mathrm{L}^{-1}$ Sigma agar (A-1296; Sigma-Aldrich, St. Louis, MO, USA), $20 \mu \mathrm{M}$ STS and cytokinins. The shoots were transferred to fresh medium every 2 weeks. On the basis of the preliminary findings, the 6-weeklong multiplication cycle (hereafter referred to as the "6wk standard multiplication cycle" applied consisted of using $0.44 \mu \mathrm{M}$ BA for the first 2 weeks, then $0.22 \mu \mathrm{M} \mathrm{BA}$ for the 2 following weeks, and $0.044 \mu \mathrm{M}$ BA plus $0.46 \mu \mathrm{M} \mathrm{Z}$ for the last 2 weeks. At the end of this 6-week-long cycle, axillary budderived shoots longer than $0.5-1 \mathrm{~cm}$ were isolated and used for subsequent culture. Subculture on the multiplication medium was successively repeated until the number of shoots produced was sufficient to enable evaluation of the modifications made to the medium aimed at improving the shoot proliferation response in the holm oak genotypes. Various experiments aimed at better defining the composition of the shoot proliferation media were designed, and the following factors were assessed using shoot cultures of genotype Q10:

(1) Cytokinins and regime

The effect of cytokinins was investigated by subculturing shoots in medium in which the cytokinin treatment $(\mu \mathrm{M})$ was varied between cycles, as follows:

Cycle 1: 0.44 BA $(2 w k) \rightarrow 0.22$ BA $(2 w k) \rightarrow 0.04$ BA $+0.46 \mathrm{Z}(2 w k)$; 6wk standard multiplication cycle

Cycle 2:0.44 BA + 0.91 Z (2wk) $\rightarrow 0.22 \mathrm{BA}+0.46 \mathrm{Z}(2 \mathrm{wk}) \rightarrow 0.04 \mathrm{BA}+0.46 \mathrm{Z}(2 \mathrm{wk})$

Cycle 3:2.28 Z (2wk) $\rightarrow 0.91 \mathrm{Z}(2 \mathrm{wk}) \rightarrow 0.46 \mathrm{Z}(2 \mathrm{wk})$

Cycle 4:0.49 2iP + 0.46 Z (2wk) $\rightarrow 0.242 \mathrm{iP}+0.46 \mathrm{Z}(2 w \mathrm{w}) \rightarrow 0.022 \mathrm{iP}+0.46 \mathrm{Z}(2 \mathrm{wk})$

For purposes of comparison, we used WPM medium supplemented with $30 \mathrm{~g} \mathrm{~L}^{-1}$ sucrose, $8 \mathrm{~g} \mathrm{~L}^{-}$

${ }^{1}$ Sigma agar, and $20 \mu \mathrm{M}$ STS.

(2) Ethylene inhibitors 
In order to evaluated the effects of $\mathrm{AgNO}_{3}$ and STS, shoots were cultured in presence of 17.6 $\mu \mathrm{M} \mathrm{AgNO}$, $20 \mu \mathrm{M}$ STS or without ethylene inhibitors (control). This $\mathrm{AgNO}_{3}$ concentration was selected in accordance with the previous findings on shoot proliferation of $Q$. rubra (Vietez et al. 2009), whereas the STS concentration was selected on the basis of our previous experience on shoot culture of holm oak and other woody species. The STS and $\mathrm{AgNO}_{3}$ were filter sterilised prior to being added to the autoclaved medium. For purposes of comparison, we used WPM medium supplemented with $30 \mathrm{~g} \mathrm{~L}^{-1}$ sucrose, $8 \mathrm{~g} \mathrm{~L}^{-1}$ Sigma agar, and BA and Z, in accordance with 6 wk standard multiplication cycle.

(3) Mineral basal medium

To study the effect of basal medium, we tested four different media: WPM, GD, Murashige and Skoog with half-strength macronutrients (1/2 MS, 1962) and SH. WPM and GD media have previously been used for shoot culture of other oak species (Vieitez et al. 2012), and SH medium has been used for maintenance of somatic holm oak embryos (Blasco et al. 2013). These basal media were supplemented with $30 \mathrm{~g} \mathrm{~L}^{-1}$ sucrose, $8 \mathrm{~g} \mathrm{~L}^{-1}$ Sigma agar, $20 \mu \mathrm{M}$ STS, and $\mathrm{BA}$ and $\mathrm{Z}$, in accordance with 6 wk standard multiplication cycle.

(4) Sucrose concentration

To evaluate the effect of concentration, sucrose was added to the basal medium at three different levels: 10, 20 and $30 \mathrm{~g} \mathrm{~L}^{-1}$. For purposes of comparison, we used WPM medium supplemented with $8 \mathrm{~g} \mathrm{~L}^{-1}$ Sigma agar, $20 \mu \mathrm{M}$ STS and BA and Z, in accordance with $6 \mathrm{wk}$ standard multiplication cycle.

(5) Agar brand

To examine the effect of the gelling agent, three different brands of agar were assayed: Vitro agar, Bacto agar (Difco Laboratories, New Jersey, USA) and Sigma agar. The agar was used at a concentration of $8 \mathrm{~g} \mathrm{~L}^{-1}$, as determined by the hyperhydricity of the shoot cultures. The different agar brands were used for shoot proliferation of different oak species, chestnut and beech, respectively. For purposes of comparison, we used WPM medium supplemented with 30 $\mathrm{g} \mathrm{L}^{-1}$ sucrose, $20 \mu \mathrm{M}$ STS, and BA and Z, in accordance with 6 wk standard multiplication cycle.

(6) Explant type

To investigate the influence of the type of explant, apical segments and nodal segments were cut from the shoots longer than $10 \mathrm{~mm}$. For purposes of comparison, we used WPM medium supplemented with $30 \mathrm{~g} \mathrm{~L}^{-1}$ sucrose, $8 \mathrm{~g} \mathrm{~L}^{-1}$ Sigma agar, $20 \mu \mathrm{M}$ STS and BA and Z was used, in accordance with $6 \mathrm{wk}$ standard multiplication cycle.

In each experiment and for each treatment, five replicate jars each containing seven explants (35 explants per treatment) were used, and the experiment was repeated twice.

To evaluate the influence of genotype in shoot proliferation, the protocol defined in the aforementioned experiments (i.e. WPM supplemented with $30 \mathrm{~g} \mathrm{~L}^{-1}$ sucrose, $8 \mathrm{~g} \mathrm{~L}^{-1}$ Sigma agar, $20 \mu \mathrm{M}$ STS and BA 
and $\mathrm{Z}$, in accordance with $6 \mathrm{wk}$ standard multiplication cycle) was also tested with another three genotypes (Q3, Q6 and E00). These genotypes were maintained in vitro under the same culture conditions as described for genotype Q10. For each genotype, five replicate jars each containing seven explants (35 explants per treatment) were used, and the experiment was repeated twice.

In all of these experiments, the following variables were measured at the end of the 6-week multiplication cycle: the percentage of explants that formed new shoots (responsive explants), mean number of new shoots $(0.5-1.0 \mathrm{~cm}$ and $>1 \mathrm{~cm}$ in length) per jar, and mean length of the longest shoot per jar.

Rooting experiments

Apical shoot segments (1.0 to $1.5 \mathrm{~cm}$ in length) of Q10, Q3, and E00 genotypes from 6-week-old cultures were used for the rooting experiments. Two different basal media were tested in a preliminary experiment: one-third strength GD macronutrients (1/3 GD) and half-strength WPM macronutrients (1/2 WPM) in combination with two auxin treatments adopted for other Quercus species (Vieitez et al. 2012). The treatments consisted of (1) immersion of the base of the shoot in a solution of indole-3butyric acid (4.92 or $9.84 \mathrm{mM}$; IBA) for one minute, and (2) culture on IBA-supplemented $(122.6 \mu \mathrm{M})$ medium for 24 or $48 \mathrm{~h}$. After auxin treatment, the shoots were subsequently transferred to the corresponding auxin-free basal medium supplemented with $20 \mu \mathrm{M} \mathrm{STS}, 30 \mathrm{~g} \mathrm{~L}^{-1}$ sucrose and $6 \mathrm{~g} \mathrm{~L}^{-1}$ Sigma agar.The cultures were incubated in darkness at $25^{\circ} \mathrm{C}$ during auxin treatment and after this period cultures were transferred to standard conditions. For each genotype (Q10, Q3, and E00), 24 shoot explants were cultured per auxin treatment and mineral medium, and the experiment was repeated at least twice.

In a subsequent experiment, the microshoots isolated from the three genotypes were maintained for 15 days on half-strength MS macronutrients (1/2 MS) medium supplemented with $20 \mu \mathrm{M} \mathrm{STS}, 30 \mathrm{~g} \mathrm{~L}^{-1}$ sucrose, $6 \mathrm{~g} \mathrm{~L}^{-1}$ Sigma agar and $17.8 \mu \mathrm{M}$ or $24.6 \mu \mathrm{M}$ IBA plus $0.54 \mu \mathrm{M} \alpha$-naphthalene acetic acid (NAA). After auxin treatment, shoots were subsequently transferred to auxin-free medium. Shoots were cultured in darkness for 7 days and then were maintained in standard conditions. For each genotype, 24 shoots were cultured per auxin treatment, and the experiment was repeated at least twice.

In these experiments, the number of shoots that had rooted out of the total number tested was determined 6-week after the auxin treatment began.

Statistical analyses

For genotypes Q, the influence of genotype in the main experimental factors (response rate, and explants with shoots $<0.5 \mathrm{~cm}$ and with shoots $\geq 5 \mathrm{~cm}$ in length) on in vitro shoot establishment was analyzed by the $\chi^{2}$ test $(\mathrm{P}<0.05)$ (Table $\left.1 \mathrm{~A}\right)$. For genotypes $\mathrm{E}$, the influence of genotype and branch diameter in the main experimental factors (response rate, and explants with shoots $<0.5 \mathrm{~cm}$ and with shoots $\geq 5 \mathrm{~cm}$ in length) on in vitro shoot establishment were analyzed by the $\chi^{2}$ test $(\mathrm{P}<0.05)$ (Table 
1B). Moreover, the influence of genotype and branch diameter on the shoot length of flushed shoot was analyzed by two way analysis of variance (ANOVA). Factors influencing axillary shoot proliferation (cytokinin and regime, basal medium, sucrose concentration, ethylene inhibitors, agar brand, explant type and genotype) (Tables 2-6; Online resources 1 and 2) were evaluated by one-way ANOVA. To determine the homogeneity of variance, Levene's test was performed prior to ANOVA, and means were compared by the least significant difference (LSD) or Dunnett's T3 test $(\mathrm{P} \leq 0.05)$ in the case of homogeneous or non-homogeneous variances, respectively. The arcsine square-root transformation was applied to data expressed as proportions prior to analysis, and the non-transformed data are presented in tables. The influence of the genotype and auxin treatment on the percentage of root formation (Online resource 3) was analysed by the $\chi^{2}$ test $(\mathrm{P}<0.05)$. SPSS for Windows (version 19.0; SPSS Inc., Chicago, IL, USA) was used for all statistical analyses.

\section{Results}

For all genotypes tested, branch segments cultured in a growth chamber produced sprouting shoots after 3-4 weeks (Table 1A, B). Shoots generally arose from lateral buds close to branch scars (Fig. 1A). In genotypes Q, branch segments collected were of a similar thickness, but in genotypes E, two thicknesses were evaluated (1-2 $\mathrm{cm}$ or 4-5 $\mathrm{cm}$ in diameter). In genotypes $\mathrm{Q}$, the total number of flushed shoots $(\mathrm{P} \leq 0.001)$ and their mean length $(\mathrm{P} \leq 0.001)$ were significantly influenced by the genotype, although apparently there was no obvious relationship between sprouting capacity and the in vitro establishment capacity (Table 1A).The mean length of the shoots ranged from 17 to $26 \mathrm{~mm}$ (Table 1A). In genotypes $\mathrm{E}$, genotype $(\mathrm{P} \leq 0.001)$ and the branch diameter $(\mathrm{P} \leq 0.001)$, and their interaction $(\mathrm{P} \leq 0.05)$ significantly affected the total number of flushed shoots (Table 1B). The mean length of flushed shoots was only significantly influenced by the branch diameter $(\mathrm{P} \leq 0.05)$, and thick segments showed a higher lengths than thinner ones. For this variable, the interaction between genotype and branch segment was not significant. For these genotypes, mean length ranged from 21 to $31 \mathrm{~mm}$ (Table 1B).

After explants had been cultured for 8 weeks, sprouting buds were observed for all genotypes tested (Table 1A and B; Fig. 1B), although there were marked differences in their in vitro performance. For genotypes Q, the response rate varied from $10.9 \%$ for clone Q7, to $72.9 \%$ for Q10 (Table 1A), and it was significantly affected by the genotype $(\mathrm{P} \leq 0.001)$. The percentage of explants with shoots $<0.5 \mathrm{~cm}$ and $\geq 0.5 \mathrm{~cm}$ in length also depended on the genotype $(\mathrm{P} \leq 0.05)$. For genotypes $\mathrm{E}$, the response rate varied from 24.6 to $49.0 \%$, and was significantly affected by the genotype ( $\mathrm{P} \leq 0.01)$ and the branch diameter $(\mathrm{P} \leq 0.05)$, but was not significantly influenced by the interaction between genotype and branch diameter (Table 1B). The percentage of explants with shoots $<0.5 \mathrm{~cm}$ and with shoots $\geq 5 \mathrm{~cm}$ in length was not significantly influenced by genotype and by diameter, although in both parameters the values were higher in the thicker branch segments (Table 1B). 
The genotypes that produced the highest proportion of shoots $\geq 0.5 \mathrm{~cm}(\mathrm{Q} 3, \mathrm{Q} 10$ and E00) were also those that were established more quickly in vitro. In all genotypes, new shoots were only observed in the initial nodal explants, whereas shoot tips necrosed and finally died.

Shoot multiplication capacity

\section{Influence of cytokinins on shoot multiplication}

Shoots excised from the initial explants were cultured for 4 weeks. The cultures were initially maintained in basal multiplication medium, and the concentration of BA was then altered every 2 weeks (from 0.89 to $0.44 \mu \mathrm{M}$ ). However, this procedure yielded poor shoot growth, hyperhydricity and the multiplication rate declined progressively over each subculture cycle. The initially low multiplication rate was improved by reducing the concentration of $\mathrm{BA}$, adding $\mathrm{Z}$ and splitting the multiplication period into three 2-week cycles, with the shoots being transferred to fresh medium at the end of each cycle. BA and $\mathrm{Z}$ were then added to the culture medium in a 6-week-long cycle (standard 6-wk multiplication cycle) as follows: $0.1 \mathrm{mg} \mathrm{L}^{-1} \mathrm{BA}$ for 2 weeks, $0.05 \mathrm{mg} \mathrm{L}^{-1} \mathrm{BA}$ for 2 weeks, and $0.01 \mathrm{mg} \mathrm{L}^{-1} \mathrm{BA}$ plus 0.1 $\mathrm{mg} \mathrm{L}^{-1} \mathrm{Z}$ for 2 weeks. The shoots were allowed to grow and elongate by successive re-culture on fresh medium, and only the newly developed shoots that exhibited vigorous growth were excised and subcultured to produce clonal shoot multiplication cultures. Six of the eight genotypes stabilized after 5 to 13 months (Table 1). As genotype Q10 grew most vigorously and was one of the first to stabilize, it was therefore selected for subsequent experiments.

Comparison of different cytokinin regimes and combinations showed that cycle 1 or the standard multiplication cycle yielded the best results for all parameters evaluated, except the proportion of responsive explants (Online resource 1). However, only the differences in the number of shoots in length $>1 \mathrm{~cm}$ and in the response percentage were significant $(\mathrm{P} \leq 0.05)$. The use of $\mathrm{Z}$ alone (cycle 3$)$ or in combination with $2 \mathrm{iP}$ (cycle 4) did not yield better results, in terms of shoot number or shoot length, than those obtained using the standard multiplication cycle. Moreover, addition of $\mathrm{Z}$ alone caused leaf thickening, which continued to increase in the follow-up subcultures.

\section{Influence of ethylene inhibitors on shoot multiplication}

In a preliminary experiment evaluating the effects of 10,20 and $30 \mu \mathrm{M}$ STS on the development of holm oak shoots (clones Q3 and Q10), no significant differences in the number of shoots or length were observed (data not shown). However, in both clones the morphology of shoots cultured in the presence of $20 \mu \mathrm{M}$ STS was more typical than that of shoots cultured in the presence of the other concentrations of STS, with lower levels of shoot tip necrosis, leaf senescence and abscission. As STS must be prepared immediately before use, which may be inconvenient, we tested the in vitro culture response in the presence of $179 \mu \mathrm{M} \mathrm{AgNO}$ and also in the absence of any ethylene inhibitor. Addition of both compounds improved the proliferation of shoot cultures for all parameters assessed (Table 2), although 
the best results were obtained with $20 \mu \mathrm{M}$ STS. Addition of STS yielded a significantly $(\mathrm{P} \leq 0.001)$ greater total number of shoots and the number of shoots in length $0.5-1.0 \mathrm{~cm}$ or more than yielded by $\mathrm{AgNO}_{3}$, although both compounds produced an increase in the length of the longest shoot.

\section{Influence of the basal medium on shoot proliferation}

In the present study, four basal media were tested during the multiplication stage (WPM, 1/2MS, SH and GD). In WPM and GD medium, the proportion of responsive explants was $100 \%$ (Table 3); however, this was significantly lower for those grown in SH medium ( $\mathrm{P} \leq 0.01)$. WPM and GD medium also yielded the best results for the number of shoots $>1 \mathrm{~cm}$, and particularly for the total number of shoots and the length of the longest shoot ( $\mathrm{P} \leq 0.001$ and $\mathrm{P} \leq 0.001$, respectively). SH and $1 / 2$ MS medium yielded poorly developed axillary buds and small leaves, whereas shoots grown in WPM and GD medium had a greater number of healthy shoots.

\section{Influence of sucrose concentration on shoot multiplication}

The concentration of the carbohydrate added to the culture medium had a significant influence on all parameters evaluated during shoot proliferation (Table 4).The best results were obtained with the highest concentration of sucrose tested $\left(30 \mathrm{~g} \mathrm{~L}^{-1}\right)$. Addition of sucrose at a concentration of $10 \mathrm{~g} \mathrm{~L}^{-1}$ yielded a significantly lower percentage of responsive explants $(\mathrm{P} \leq 0.001)$ than generated by the other concentrations tested $\left(20\right.$ and $\left.30 \mathrm{~g} \mathrm{~L}^{-1}\right)$. The highest sucrose concentration yielded a significantly greater total number of shoots and number of shoots in length $0.5-1.0 \mathrm{~cm}(\mathrm{P} \leq 0.001)$, and the increase in the number of shoots of length $>1 \mathrm{~cm}$ was particularly notable. The highest concentration of sucrose also yielded significantly longer shoots $(\mathrm{P} \leq 0.05)$ than yielded by the other two concentrations.

\section{Influence of agar brand on shoot multiplication}

The three brands of agar tested had similar effects for responsive explants and total number of shoots produced (Table 5). However, Sigma agar yielded a greater number of shoots of more than $1 \mathrm{~cm}$ in length and of better quality than those yielded by either Bacto or Vitro agar (Table 5).

\section{Influence of explant type on shoot multiplication}

In this experiment, we evaluated the proliferation capacity of apical and nodal segments. Both types responded well to micropropagation, with a response rate of $100 \%$. Nodal explants yielded a slightly higher total number of shoots, number of shoots $>1 \mathrm{~cm}$ in length, and number of shoots of length $0.5-$ $1.0 \mathrm{~cm}$, whereas apical explants yielded shoots of longer mean length. However, there were no significant differences in any of the parameters studied (Online resource 2). Both types of explants can therefore be routinely used for multiplication. 


\section{Influence of genotype on shoot multiplication}

The effect of genotype on holm oak proliferation is shown in Table 6. The procedure established in the experiments for propagating shoots of genotype Q10 was also tested with the other genotypes (Q3, Q6 and E00). Genotype had a significant effect $(\mathrm{P}<0.001)$ on all parameters evaluated, except the number of shoots in length $0.5-1.0 \mathrm{~cm}$. Genotypes Q10 and E00 yielded the highest numbers of shoots and the longest shoots. Although differences in the percentage of responsive explants, number of shoots and shoot length were obtained, the rate of multiplication of explants of all genotypes cultured under these conditions was acceptable, and the explants grew vigorously and appeared healthy (Table 6; Fig. 1C, D).

\section{Rooting capacity}

None of the auxin treatments previously tested in other Quercus species promoted adventitious rooting in any of the three genotypes of holm oak tested. Rooting only occurred in shoots cultured for 15 days on $1 / 2$ MS medium supplemented with $14.8 \mu \mathrm{M}$ or $24.6 \mu \mathrm{M}$ IBA and $0.54 \mu \mathrm{M}$ NAA (Fig. 1E, F). Rooting rates were significantly influenced by the genotype $(\mathrm{P} \leq 0.01)$ but not by the IBA concentration (Online resource 3). The best results were obtained with genotype E00 (18.8\%) and 17.8 $\mu \mathrm{M}$ IBA. Roots generally began to emerge during the fourth and fifth week after the start of the rooting treatment.

\section{Discussion}

To our knowledge, this is the first report of culture initiation, shoot production and rooting in mature $Q$. ilex trees. Although standardised procedures for the micropropagation of the most important oak species by axillary budding have been reported (Vieitez et al. 2012), recalcitrance is still a major problem for the clonal propagation of the mature stage of many tree species, including holm oak. The use of cultures obtained from mature material is a challenge regarding the widespread application of micropropagation techniques in woody species. In general, micropropagation of mature trees is possible when tissues with juvenile characteristics, such as basal shoots and stump sprouts, are used (Ballester et al. 2016; Bonga 2017). However, for plant material obtained from the crowns of mature trees, micropropagation is of limited success, and low shoot multiplication and rooting rates are generally achieved (Vieitez et al. 2007; Wendling et al. 2014). As human management of the dehesas usually involves removal of the shrub layer and clearance of the arboreal stratum (Mesías et al. 2010), holm oak trees do not usually have basal shoots. In the absence of mature material with juvenile physiological characteristics, an alternative procedure based on forced flushing of branch segments can be used to produce epicormic shoots, which are a source of more reactive and reinvigorated explants (Martínez et al. 2012). In the present study, this method enabled the establishment and proliferation of shoot cultures from material derived from the crowns of mature trees. Another advantage of forcing shoots for use in in vitro propagation is the low level of microbiological contamination associated with this type of material. 
Holm oak sprouting shoots was also influenced by the genotype and the diameter of branch segments. The micropropagation capacity varies depending on the genotype considered (Monteuuis 2016). The present findings showed that holm oak tree genotypes derived from 30 to $100 \mathrm{yr}$-old in situ selected ortets could be established in vitro, although differences were observed between the clones, both at the culture initiation stage and during the subsequent micropropagation by axillary budding. Differences between species and also between different genotypes of the same species have been reported in woody plants such as American oak species (Vieitez et al. 2009), strawberry tree (Gomes et al. 2010) or black alder (San José et al. 2013).

Mature material can be rejuvenated by subculture of in vitro shoots, especially in culture medium supplemented with cytokinins (Wendling et al. 2014). One of the most important factors in micropropagation is the type and concentration of cytokinin used (Van Staden et al. 2008). In holm oak, the use of low levels of the cytokinins BA and zeatin improved the proliferation of shoot cultures, possibly because of the levels of endogenous cytokinins present. In European chestnut, shoot cultures derived from crown material exhibited higher amounts of endogenous cytokinins than shoot cultures derived from basal sprouts from the same mature tree (Vidal 2002). BA and zeatin are the cytokinins most commonly used for shoot proliferation in Fagaceae species. Cytokinins have been used in a similar way for shoot proliferation in American oak species, with successful results (Vieitez et al. 2009). In beech, shoot proliferation has also been reported to be improved by including both BA with zeatin (Vieitez et al. 2003). The addition of zeatin possibly reduces the imbalance in levels of endogenous zeatin or its various derivatives (Vieitez et al. 2003). Moreover, the fortnightly transfer of cultures to fresh medium in a 6-week subculture cycle also helped to increase the multiplication rate of the genotypes tested. Changing the medium during the subculture cycle has been found to be required for axillary shoot multiplication of other members of the Fagaceae family, more specifically Fagus spp. (Vieitez et al. 1993a), Q. robur (Vieitez et al. 1994), and Q. alba and Q. bicolor (Vieitez et al. 2009). The study findings showed that ethylene plays an important role in holm oak shoot proliferation. The beneficial effects of ethylene inhibitors on organogenesis have been extensively reported in relation to plant regeneration (Moshkov et al. 2008). Thus, the effects of ethylene can be reduced by adding silver ions $\left(\mathrm{Ag}^{+}\right)$, which are generally incorporated in culture medium as either $\mathrm{AgNO}_{3}$ or STS. Although it has been suggested that STS would be better at supplying $\mathrm{Ag}^{+}$than $\mathrm{AgNO}_{3}$ (Gaspar et al. 1996), information on the use of STS for improving morphogenetic processes is limited. Steinitz et al. (2010) found that STS was better than $\mathrm{AgNO}_{3}$ for adventitious root induction and shoot growth and suggested that the formation of the STS complex preserves $\mathrm{Ag}^{+}$cations in a dissolved state and thus may also prevent precipitation of the cations. These authors suggested that the better performance of STS may be due to the beneficial effect $\mathrm{S}_{2} \mathrm{O}_{3}{ }^{2}$-anions on cell differentiation and growth in tissue culture. Similarly, the inclusion of $20 \mu \mathrm{M}$ STS in the rooting medium used for Eucalyptus globulus microcuttings has been shown to significantly improve the capacity for adventitious rooting in addition to enhancing plant quality by increasing shoot and leaf growth (Vieitez A.M. pers. comm.). 
In the present study, the highest shoot multiplication scores for clone Q10 were obtained with WPM and GD medium. These mineral formulations are usually used in micropropagation studies in the family Fagaceae, including Quercus species (Vieitez et al. 2012). In the only study on micropropagation by axillary budding in $Q$. ilex, WPM medium was also used to multiply material of juvenile origin (Liñan et al. 2011). The main difference between the different mineral media evaluated is in the nitrate content, which was higher in 1/2MS and SH than in GD and WPM. The influence of the nitrogen source and concentration on in vitro morphogenic processes has been mentioned for other woody species (Dal Vesco and Guerra 2001; Gomes and Canhoto 2009).

Sucrose is the most widely used source of carbohydrate for the axillary shoot proliferation of Quercus spp., although the concentration used varies depending on the species or even type of culture under consideration (El Kbiach et al. 2004; Ostrolucka et al. 2007; Vieitez et al. 2009; Vengadesan and Pijut 2009). For holm oak, Liñan et al. (2011) used $20 \mathrm{~g} \mathrm{~L}^{-1}$ sucrose to proliferate axillary shoots established from material of juvenile origin. However, we found that use of $30 \mathrm{~g} \mathrm{~L}^{-1}$ sucrose was more effective for promoting axillary shoot proliferation.

We also found that the brand of agar is important for proliferation of holm oak shoot. The use of agar as a gelling agent can affect the growth of in vitro cultures, mainly affecting the levels of vitrification and necrosis of cultures (Scholten and Pierik 1998; Pereira-Netto et al. 2007). Although Bacto agar and Vitro agar have previously been used for multiplying diverse species of Quercus (Vieitez et al. 1993b; Vieitez et al. 1994; Ostrolucka et al. 2007; Vieitez et al. 2009), we found that use of Sigma agar improved the appearance and proliferation of holm oak shoot cultures. Sigma agar has also been used in other woody species including Fagus sylvatica and F. orientalis (Vieitez et al. 2003), Paulownia tomentosa (Corredoira et al. 2008) and Cedrela odorata (Millán-Orozco et al. 2011). One possible explanation for the differences is the presence of impurities, inhibitory compounds or limited diffusion of nutrients (Pereira-Netto et al. 2007 and references therein).

With respect to the type of explant used for subculture, the findings reported in the literature are contradictory. In chestnut, fewer axillary shoots are produced from shoot tips than from nodal segments (Vieitez et al. 2007), presumably due to the inhibitory effects of apical dominance on the development of axillary buds. By contrast, in Q. rubra, lower multiplication rates were obtained with nodal explants than with basal and apical explants (San José et al. 1990). Likewise, Liñan et al. (2011) reported that in $Q$. ilex, the growth of basal explants was significantly higher than apical and/or mid-stem explants. In the present study, the type of explant used did not significantly affect the multiplication capacity of the mature $Q$. ilex clones tested.

The maintenance of the shoot cultures for a prolonged period, by successive subculture, led to better adaptation and growth response in these in vitro cultures. This may be due to rejuvenation of the material, as in vitro culture is considered to contribute to this process (Bonga and von Aderkas 1992; Preece 2008). However, despite the apparent rejuvenation of holm oak cultures, the rooting capacity of the shoot cultures was relatively low. In present, rooting was only obtained when shoots were cultured 
with IBA and NAA for 15 days. The incorporation of both auxins has also been reported in rooting protocols of diverse species of Quercus (Ostrolucka et al. 2007). The time until appearance of roots in holm oak was longer than that previously reported for other members of the Fagaceae family, including oak and chestnut species (Vieitez et al. 2007; Vieitez et al. 2009).

Adventitious root formation is a key step in the clonal propagation of forest trees and is closely related to the ontogenetic and physiological state of the mother plant (Ballester et al. 2009; Monteuuis 2016). Although little is known about the rooting of axillary shoot cultures established from crown material obtained from woody plants, in general the rooting rates are lower than yielded by basal shoots. Martínez et al. (2012) reported that shoot cultures derived from the crown of a $Q$. robur tree displayed a low rooting capacity (3.3\%), whereas shoot cultures collected from the same mature tree, but derived from basal sprouts, displayed a much higher rooting capacity (71.5\%). Similar results have been reported for chestnut (Sánchez and Vieitez 1991) and Sequoia sempervirens (Bon et al. 1994). Considering the material used in the present study, clones Q10 and Q3 were 100 years old, whereas E00 was 30 years old. This difference in age may also explain why the crown material from Q10 and Q3 was more recalcitrant to rooting than the crown material from E00. Contrary to the age effect in the rooting step, the observed differences in establishment and proliferation do not appear to be related to tree age, as the material that yielded the highest proliferation rates and early stabilization was amongst the oldest tested.

In conclusion, the current study demonstrates that material from mature holm oak trees can be successfully cultured in vitro. Although the protocol requires further improvement, particularly as regards the rooting rates, the findings indicate that large scale clonal propagation of this species may eventually be possible. Finally, leaves and shoot apices derived from axillary shoot cultures of holm oak established and proliferated in the present study proved ideal initial explants for inducing somatic embryogenesis (Martínez et al. 2017, in the present volume), which is considered a strong indication of rejuvenation (Bonga 2017). Both organogenesis and somatic embryogenesis would facilitate the vegetative propagation of holm oak, thereby contributing to the restoration of valuable ecosystems.

\section{Funding}

This research has been partly funded by Ministerio de Economía y Competitividad, MINECO, Spain (AGL 2013-47400-C4-3R and AGL2016-76143-C4-4-R).

\section{Acknowledgements}

We thank Dr M Toribio for kindly providing the plant material used in this study. We also thank JC Suárez San Martín for technical support. 


\section{References}

Alaska-Kennedy Y, Yoshida H, Takahata Y (2005) Efficient plant regeneration from leaves of rapeseed (Brassica napus L.): the influence of $\mathrm{AgNO}_{3}$ and genotype. Plant Cell Rep 24: 649-654

Bairu MW, Stirk WA, Dolezal K, Van Staden JV (2007) Optimizing the micropropagation protocol for the endangered Aloe polyphylla: can meta-polin and its derivates serve as replacement for benzyladenine and zeatin?. Plant Cell Tissue Organ Cult 90:15-23

Ballester A, Corredoira E, Vieitez AM (2016) Limitations of somatic embryogenesis in hardwood trees. In: Park Y-S, Bonga JM, Moon H-K (eds) Vegetative propagation of forest trees. National Institute of Forest Science (Nifos), Seoul, Korea, pp 56-74

Ballester A, Vidal N, Vieitez AM (2009) Developmental stages during in vitro rooting of hardwood trees from material with juvenile and mature characteristics. In: Niemi K, Scagel C (eds) Adventitious root formation of forest trees and horticultural plants-from genes to applications. Research Signpost, Kerala, India, pp 277-296

Benson E (2000) In vitro plant recalcitrance: an introduction. In Vitro Cell Dev Biol Plant 36:141-148

Blasco M, Barra A, Brisa C, Corredoira E, Segura J, Toribio M, Arrillaga I (2013) Somatic embryogenesis in holm oak male catkins. Plant Growth Regul 71:261-270

Bon MC, Riccardi F, Monteuuis O (1994) Influence of phase change within a 90-year-old Sequoia sempervirens on its in vitro organogenic capacity and protein patterns. Trees 8:283-287

Bonga JM (2017) Can explant choice help resolve recalcitrance problems in in vitro propagation, a problem still acute especially for adult conifers? Trees 31:781-789

Bonga JM, Klimaszewska KK, von Aderkas P (2010) Recalcitrance in clonal propagation, in particular of conifers. Plant Cell Tiss Organ Cult 100:241-254

Bonga JM, von Aderkas P (1992) In vitro culture of trees. Kluwer Academic Publishers, Dordrecht

Burgos L, Alburquerque N (2003) Ethylene inhibitors and low kanamycin concentrations improve adventitious regeneration from apricot leaves. Plant Cell Rep 31:1167-1174

Corcobado T, Cubera E, Moreno G, Solla A (2013) Quercus ilex forests are influenced by annual variations in water table, soil water deficit and fine root loss caused by Phythophtora cinnamomi. Agric For Meteorol 169:92-99

Corredoira E, Ballester A, Ibarra M, Vieitez AM (2015) Induction of somatic embryogenesis in leaf and shoot apex explants of shoot cultures derived from adult Eucalyptus globulus and Eucalyptus saligna x E. maidenii trees. Tree Physiol 35:663-677

Corredoira E, Ballester A, Vieitez AM (2008) Thidiazuron-induced high frequency plant regeneration from leaf explants of Paulownia tomentosa mature trees. Plant Cell Tissue Organ Cult 95:197-208

Corredoira E, San-José MC, Vieitez AM (2012) Induction of somatic embryogenesis from different explants of shoot cultures derived from young Quercus alba trees. Trees 26:881-891

Correia S, Lopes ML, Canhoto JM (2011) Somatic embryogenesis induction system for cloning an adult Cyphomandra betacea (Cav.) Sendt. (tamarillo). Trees 25:1009-1020 
Council of Europe, UNEP \& ECNC (1996) The Pan-European biological and landscape diversity strategy: a vision for Europe's natural heritage. European Centre for Nature Conservation, Tilburg.

Dal Vesco LL, Guerra MP (2001) The effectiveness of nitrogen sources in Feijoa somatic embryogenesis. Plant Cell Tissue Org Cult 64:19-25

Ďurkovič J, Mišalová A (2008) Micropropagation of temperate hardwoods: an overview. Functional Plant Science 2:1-19

El Kbiach ML, Lamarti A, Abdali A, Badoc A (2004) Micropropagation du Chêne-liège (Quercus suberL.) par bourgeonnement axillaire. Acta Bot Gallica 151:415-427

Gaspar T, Kevers C, Penel C, Greppin H, Reid DM, Thorpe TA (1996) Plant hormones and plant growth regulators in plant tissue culture. In Vitro Cell Dev Biol Plant 32: 272-289

George EF, Debergh PC (2008) Micropropagation: uses and methods. In: George EF, Hall MA, de Klerk GJ (eds) Plant propagation by tissue culture, 3rd edn. Springer, Dordrecht, pp 29-64

Gomes F, Canhoto JM (2009) Micropropagation of strawberry tree (Arbustus nedo L.) from adult plants. In Vitro Cell Dev Biol Plant 45:72-82

Gomes F, Simỡes M, Lopes ML, Canhoto JM (2010) Effect of plant growth regulators and genotype on the micropropagation of Arbutus unedo L. (strawberry tree). New Biotechnol 27:882-892

Gresshoff PM, Doy CH (1972) Development and differentiation of haploid Lycopersicon esculentum. Planta 107:161-170

Howell SH, Lall S, Che P (2003) Cytokinins and shoot development. Trends Plant Sci 8:453-459

Huntsinger L, Campos P, Starrs PF, Oviedo JL, Díaz M, Standiford RB, Montero G (2013) Working landscapes of the spanish dehesa and the California oak woodlands: An Introduction. In: Campos P, Huntsinger L, Oviedo JL et al. (eds) Mediterranean oak woodland working landscapes. Springer, Dordrecht, pp 3-23

L'Helgoual'ch M, Espagnac H (1987) First observations on the adventitious rhizogenic capacity of holm oak (Quercus ilex L.). Ann Sci For 44:325-334

Liñan J, Cantos M, Troncoso J, García JL, Fernández A, Troncoso A (2011) Some propagation methods for cloning holm oak (Quercus ilex L.) plants. Cent Eur J Biol 6: 359-364

Liu X, Pijut P (2008) Plant regeneration from in vitro leaves of mature black cherry (Prunus serotina). Plant Cell Tissue Organ Cult 94:113-123

Lloyd G, McCown B (1980) Commercially-feasible micropropagation of mountain laurel, Kalmia latifolia, by use of shoot-tip culture. Comb Proc Int Plant Prop Soc 30: 421-427

Martínez MT, Vidal N, Ballester A, Vieitez AM (2012) Improved organogenic capacity of shot cultures from mature pedunculate oak trees through somatic embryogenesis as rejuvenation technique. Trees 26:321-330

Martínez MT, Vieitez AM, Corredoira E (2015) Improved secondary embryo production in Quercus alba and Quercus rubra by activated charcoal, silver thiosulphate and sucrose: influence of embryogenic explant used for subculture. Plant Cell Tissue Organ Cult 212:531-546 
Martínez MT, Vieitez AM, Corredoira E, Cernadas MJ, Montenegro R, Ballester A, Vieitez FJ, San José MC (2017) Vegetative propagation of adult Quercus ilex L. (holm oak) trees. I. Micropropagation by axillary budding. Plant Cell Tissue Organ Cult (in press)

Mauri PV, Manzanera JA (2005) Protocol of Somatic Embryogenesis: holm oak (Quercus ilex L.). In: Jain SM, Gupta PK (eds) Protocol for somatic embryogenesis in woody plants. Springer, Dordrecht, pp 469-482

McCown BH (2000) Recalcitrance of woody and herbaceous plants: dealing with genetic predeterminism. In vitro Cell Dev Biol Plant 36:149-154

Mesías FJ, Pulido F, Gaspar P, Escribano M, Pulido AF (2010) Management of spanish rangelands (Dehesas): an example of sustainable use. In: Veress B, Szigethy J (eds) Horizons in earth science research. Vol. 1.Nova Science Publishers, New York, pp 163-186

Millán-Orozco L, Corredoira E, San José MC (2011) In vitro rhizogenesis: histoanatomy of Cedrela odorata (Meliaceae) microcuttings. Rev Biol Trop 59: 447-453

Monteuuis O (2016) Micropropagation and production of forest trees. In: Park Y-S, Bonga JM, Moon H-K (eds) Vegetative propagation of forest trees. National Institute of Forest Science (NIFOS), Korea, pp:32-55

Monteuuis O, Doulbeau S, Verdeil JL (2008) DNA methylation in different origin clonal offspring from mature Sequoiadrendron giganteum genotype. Trees 22:779-784

Moreno G, Pulido F (2009) The functioning, management, and persistence of dehesas. In: RigueiroRodríguez A, McAdam, J, Mosquera-Losada MR (eds) Agroforestry in Europe. Advances in agroforestry. Springer, Netherlands, pp 127-160

Moshkov IE, Novikova GV, Hall MA, George EF (2008) Plant growth regulators III: ethylene. In: George EF, Hall MA, de Klerk GJ (eds) Plant Propagation by Tissue Culture, vol 1. 3rd edn. Springer, The Netherlands, pp 239-248

Murashige T, Skoog F (1962) A revised medium for rapid growth and bioassays with tobacco tissue culture. Physiol Plant 15:473-497

Ostrolucká MG, Gajdosová A, Libiaková G (2007) Protocol for micropropagation of Quercus spp. In: Jain SM, Häggman (eds) Protocols for micropropagation of woody trees and fruits. Springer, The Netherlands, pp 85-91

Park JS, Naing AH, Kim CK (2016) Effects of ethylene on shoot initiation, leaf yellowing, and shoot tip necrosis in rose. Plant Cell Tissue Organ Cult 127:425-431

Pereira-Netto AB, Petkowic CLO, Cruz-Silva TA, Gazzoni MT, Mello AFP, Silveira JLM (2007) Differential performance of marabakaido apple rootstock shoots grown in culture media containing different agar brands: dynamic rheological analysis. In vitro Cell Dev Biol Plant 43:356-363

Plieninger T, Pulido FJ, Schaich H (2004) Effects of land-use and landscape structure on holm oak recruitment and regeneration at farm level in Quercus ilex L. dehesas. J Arid Environ 57:345-364 
Poothong S, Reed BM (2014) Modeling the effects of mineral nutrition for improving growth and development of micropropagated red raspberries. Sci Hort 165:132-141

Preece J (2008) Stock plant physiological factors affecting growth and morphogenesis. In: George EF, Hall MA, de Klerk GJ (eds) Plant propagation by tissue culture, 3rd edn. Springer, Dordrecht, pp 403 422

Qin YH, Zhang SL, Zhang LX, Zhu DY, Syed A (2005) Response to in vitro strawberry to silver nitrate $\left(\mathrm{AgNO}_{3}\right)$. HortScience 40: 747-751

Ramage CM, Williams RR (2002) Mineral nutrition and plant morphogenesis. In vitro Cell Dev Biol Plant 38:116-124

Reis LB, PaivaNeto VB, Toledo Picoli EA, Costa NGC, Rêgo MM, Carvalho CR, Finger FL, Otoni WC (2003) Axillary bud development of passion fruit as affected by ethylene precursor and inhibitors. In Vitro Cell Dev Biol Plant 39:618-622

Ruíz de la Torre J (2006) Flora mayor. Organismo Autónomo de Parques Nacionales. Dirección General para la Biodiversidad, Madrid

San José MC, Corredoira E, Martínez MT, Vidal N, Valladares S, Mallón R, Vieitez AM (2010) Shoot apex explants for induction of somatic embryogenesis in mature Quercus robur L. trees. Plant Cell Rep 29:661-67

San José MC, Janeiro LV, Corredoira E (2013) Micropropagation of threatened black alder. Silva Fenn $47: 1-12$

San José MC, Vieitez AM, Ballester A (1990) Clonal propagation of juvenile and adult trees of sessile oak by tissue culture. Silvae Genet 39:50-55

Sánchez MC, Vieitez AM (1991) In vitro morphogenetic competence of basal sprouts and crown branches of mature chestnut. Tree Physiol 8:59-70

Sánchez ME, Caetano P, Ferraz J, Trapero A (2002) Phytophthora diseases of Quercus ilex in southwestern Spain. For Pathol 32: 5-18

Schenk RU, Hildebrand AC (1972) Medium and techniques for induction of growth of monocotyledonous and dicotyledonous plant cell culture. Can J Bot 50:199-204

Scholten HJ, Pierik RLM (1998) Agar as a gelling: differential biological effects in vitro. SciHort 77:1009-116

SPSS for Windows (2010) Guía Breve de IBM SPSS Statistics 19.SPSS Inc., IBM Company, Chicago, IL, USA, pp 171

Steinitz B, Barr N, Tabib Y, Vaknin Y, Bernstein N (2010) Control of in vitro rooting and plant development in Corymbia maculate by silver nitrate, silver thiosulphate and thiosulphate ion. Plant Cell Rep 29: 1315-1323

Thorpe T, Stasolla C, Yeung EC, de Klerk G-J, Roberts A, George EF (2008) The components of plant tissue culture media II: organic additions, osmotic and $\mathrm{pH}$ effects, and support systems. In: George 
EF, Hall MA, de Klerk GJ (eds) Plant propagation by tissue culture, 3rd edn. Springer, Dordrecht, pp $115-174$

Van Staden J, Zazimalova E, George EF (2008) Plant growth regulators II: Cytokinins, their analogues and antagonists. In: George EF, Hall MA, de Klerk GJ (eds) Plant propagation by tissue culture, 3rd edn. Springer, Dordrecht, pp 205-226

Vengadesan G, Pijut PM (2009) Somatic embryogenesis and plant regeneration of northern red oak (Quercus rubra L.).Plant Cell Tissue Organ Cult 97: 141-149

Vidal N (2002) Relación entre el contenido endógeno de reguladores de crecimiento, el estado ontogenético y la capacidad de enraizamiento de brotes de castaño y roble cultivados in vitro. Tesis Doctoral. Universidad de Santiago de Compostela, Spain

Vieitez AM, Corredoira E, Ballester A, Muñoz F, Durán J, Ibarra M (2009) In vitro regeneration of important North American oak species Quercus alba, Quercus bicolor and Quercus rubra. PlantCellTissueOrganCult 98:135-145

Vieitez AM, Corredoira E, Martínez MT, San José MC, Sánchez C, Valladares S, Vidal N, Ballester A (2012). Application of biotechnological tools to Quercus improvement. Eur J Forest Res 131:519-539

Vieitez AM, Ferro EM, Ballester A (1993a) Micropropagation of Fagus sylvatica L. In Vitro Cell Dev Biol Plant 29:183-188

Vieitez AM, Pintos F, San José MC, Ballester A (1993b) In vitro shoot proliferation determined by explant orientation of juvenile and mature Quercus rubra L. Tree Physiol 12:107-117

Vieitez AM, San José MC, Sánchez MC, Ballester A (2003) Micropropagation of Fagus spp. In: Jain SM, Ishii K (eds) Micropropagation of woody trees and fruits. Kluwer Academic Publishers, Netherlands, pp 181-215

Vieitez AM, Sánchez MC, Amomarco JB, Ballester A (1994) Forced flushing of branch segments as a method for obtaining reactive explants of mature Quercus robur trees for micropropagation. Plant Cell Tissue Organ Cult 37:287-295

Vieitez AM, Sánchez MC, García-Nimo ML, Ballester A (2007) Protocol for micropropagation of Castanea sativa Mill. In: Jain SM, Häggman H (eds) Protocols for micropropagation of woody trees and fruits. Springer, Heidelberg, pp 299-312

Wendling I, Trueman SJ, Xavier A (2014) Maturation and related aspects in clonal forestry-part II: reinvigoration, rejuvenation and juvenility maintenance. New For 45:473-486 


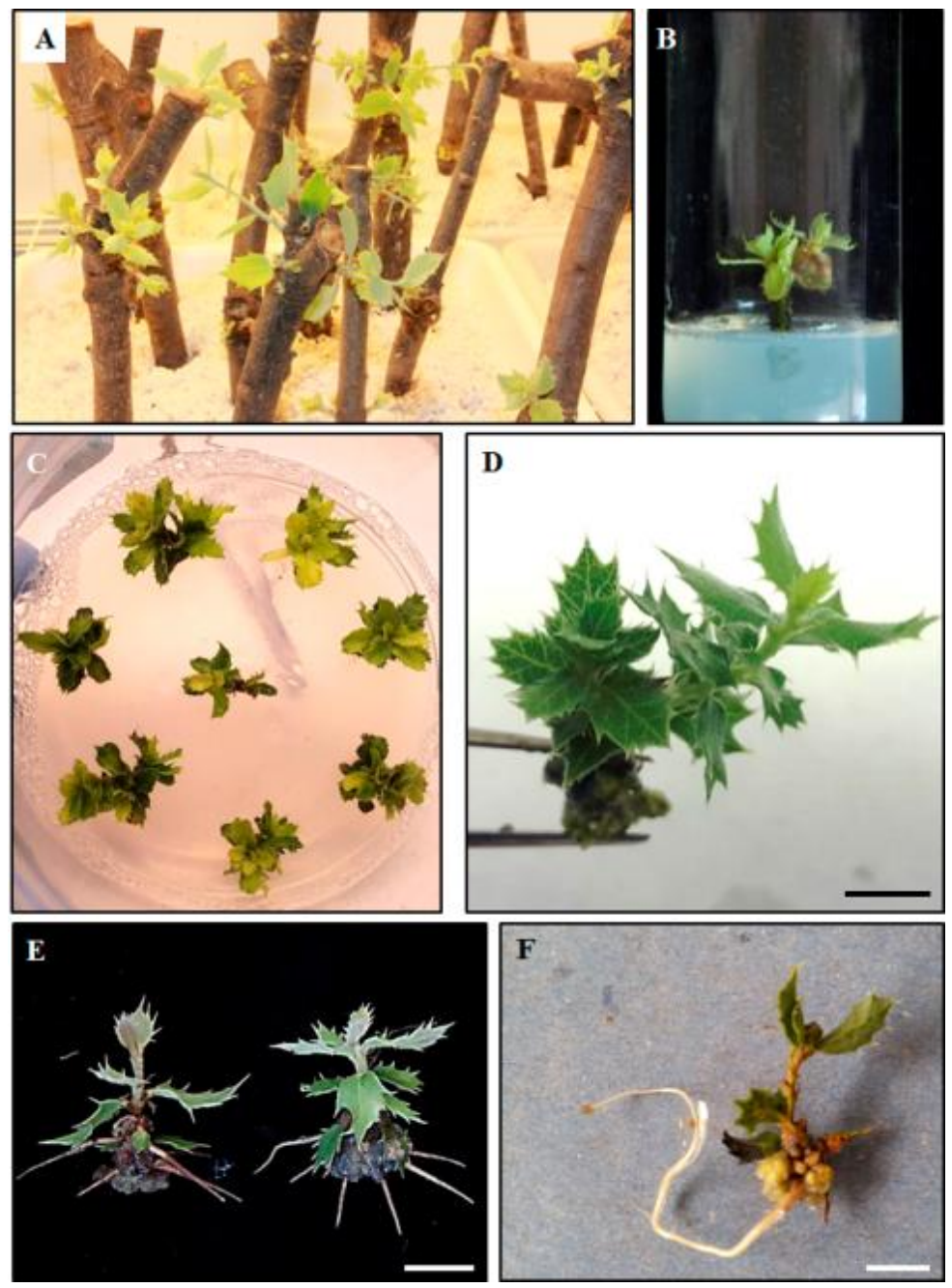

Figure 1. Micropropagation by axillary budding of mature holm oak (Quercus ilex L.) genotypes. A. Sprouting branch segments under growth chamber artificial conditions (Wide tray: $32 \mathrm{~cm}$ ). B. Axillary shoot development arising from a nodal explant after 8 weeks of primary culture (Diameter of the tube: $30 \mathrm{~mm}$ ). C. Shoot multiplication of genotype Q3 after a 6-week standard multiplication cycle (Diameter of the jar: $90 \mathrm{~mm}$ ). D. Morphological appearance of shoot from genotype Q10 after 6 weeks of culture on the multiplication medium. E, F. In vitro rooted microshoots of clone Q10 (E) and E00 (F) after 6 weeks of culture on the rooting medium supplemented with $17.8 \mu \mathrm{M}$ IBA and $0.54 \mu \mathrm{M}$ NAA. D, E, F, scale bar $1 \mathrm{~cm}$. 
Table 1A. Sprouting responsiveness of branch segments $(2-4 \mathrm{~cm}$ in branch diameter) and in vitro establishment success of the sprouting shoots produced for the genotypes Q (100 years old) investigated.

\begin{tabular}{|c|c|c|c|c|c|c|c|c|c|}
\hline \multirow[t]{2}{*}{ Genotype } & \multicolumn{3}{|c|}{ Sprouting shoots produced $^{1}$} & \multicolumn{6}{|c|}{ Responsiveness to in vitro establishment ${ }^{2}$} \\
\hline & $\begin{array}{c}\text { Number of } \\
\text { branch } \\
\text { segments }\end{array}$ & $\begin{array}{l}\text { Total number of } \\
\text { flushed shoots } \\
\text { harvested }^{3}\end{array}$ & $\begin{array}{c}\text { Average } \\
\text { length of } \\
\text { harvested } \\
\text { shoots } \\
(\mathrm{mm})^{4}\end{array}$ & $\begin{array}{c}\text { Number of } \\
\text { initial explants }\end{array}$ & $\begin{array}{c}\text { Contamination } \\
\text { rate } \\
\%^{6}\end{array}$ & $\begin{array}{c}\text { Response } \\
\text { rate } \\
\%\end{array}$ & $\begin{array}{c}\text { Explants with } \\
\text { shoots }<0.5 \mathrm{~cm} \\
\%^{6}\end{array}$ & $\begin{array}{c}\text { Explants with } \\
\text { shoots } \geq 0.5 \mathrm{~cm} \\
\%_{0}^{6}\end{array}$ & $\begin{array}{l}\text { Period needed for } \\
\text { stabilization } \\
\text { (months) })^{7}\end{array}$ \\
\hline $\mathbf{Q 2}$ & 10 & $61(6.1)$ & $25.5 \pm 8.7$ & 77 & $5.2(4)$ & $18.2(14)$ & $16.9(13)$ & $1.3(1)$ & Lost \\
\hline Q3 & 7 & $27(3.8)$ & $19.3 \pm 3.3$ & 38 & 0 & $65.8(25)$ & $31.6(12)$ & $34.2(13)$ & 9 \\
\hline Q6 & 9 & $76(8.4)$ & $26.1 \pm 3.0$ & 99 & $3(3)$ & $20.2(20)$ & $11.1(11)$ & $9.1(9)$ & 13 \\
\hline Q7 & 10 & $53(5.3)$ & $21.3 \pm 4.8$ & 64 & $1.6(1)$ & $10.9(7)$ & $7.8(5)$ & $3.1(2)$ & Lost \\
\hline Q8 & 7 & $53(7.6)$ & $16.9 \pm 2.6$ & 51 & $2(1)$ & $49.0(25)$ & $39.2(20)$ & $9.8(5)$ & 12 \\
\hline \multirow[t]{2}{*}{ Q10 } & 13 & $42(3.2)$ & $18.7 \pm 5.2$ & 48 & 0 & $72.9(35)$ & $39.6(19)$ & $33.3(16)$ & 12 \\
\hline & & $\begin{array}{c}\chi^{2} \\
P \leq 0.001\end{array}$ & $\begin{array}{c}\text { F-test } \\
\mathrm{P} \leq 0.001\end{array}$ & $\chi^{2}$ & & $\mathrm{P} \leq 0.001$ & $\mathrm{P} \leq 0.05$ & $\mathrm{P} \leq 0.05$ & \\
\hline
\end{tabular}

${ }^{\mathrm{I}}$ Evaluated after 4 weeks on growth chamber.

${ }^{2}$ Evaluated after 8 weeks of in vitro culture.

${ }^{3}$ The mean number of flushed shoot per branch is indicated in parenthesis.

${ }^{4}$ Average shoot length \pm standard deviation.

${ }^{5}$ Response rate is defined as the initial explants with sprounting buds after 8 weeks of in vitro culture.

${ }^{6}$ The actual numbers corresponding to the $\%$ are indicated in parenthesis.

${ }^{7}$ Cultures are considered stable when uniform and continuous growth is achieved in vitro.

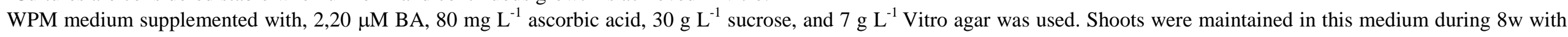
transferences each $2 \mathrm{w}$ and in the last $2 \mathrm{wk}$ BA was reduced to $0.89 \mu \mathrm{M}$.

The influenced of genotype on the sprouting responsiveness and the in vitro establishment was analyzed by chi-squared $\left(\chi^{2}\right)$ and one-way ANOVA. ns not significant. 
Table 1B. Sprouting responsiveness of branch segments and in vitro establishment success of the sprouting shoots produced for the genotypes E (30 years old) investigated.

\begin{tabular}{|c|c|c|c|c|c|c|c|c|c|}
\hline \multirow{2}{*}{$\begin{array}{l}\text { Genotype } \\
\text { (Branch } \\
\text { diameter) }\end{array}$} & \multicolumn{3}{|c|}{ Sprouting shoots produced $^{1}$} & \multicolumn{6}{|c|}{ Responsiveness to in vitro establishment $^{2}$} \\
\hline & $\begin{array}{l}\text { Number of } \\
\text { branch } \\
\text { segments }\end{array}$ & $\begin{array}{l}\text { Total number of } \\
\text { flushed shoots } \\
\text { harvested }^{3}\end{array}$ & $\begin{array}{c}\text { Average } \\
\text { length of } \\
\text { harvested } \\
\text { shoots } \\
(\mathrm{mm})^{4}\end{array}$ & $\begin{array}{c}\text { Number of } \\
\text { initial explants }\end{array}$ & $\begin{array}{c}\text { Contamination } \\
\text { rate } \\
\%^{6}\end{array}$ & $\begin{array}{c}\text { Response } \\
\text { rate } \\
\%^{5,6}\end{array}$ & $\begin{array}{c}\text { Explants with } \\
\text { shoots }<0.5 \mathrm{~cm} \\
\%^{6}\end{array}$ & $\begin{array}{c}\text { Explants with } \\
\text { shoots } \geq 0.5 \mathrm{~cm} \\
\%_{0}^{6}\end{array}$ & $\begin{array}{l}\text { Period needed for } \\
\text { stabilization } \\
(\text { months })^{7}\end{array}$ \\
\hline E2 $(1-2 \mathrm{~cm})$ & 15 & $213(14)$ & $21.1 \pm 2.6$ & 102 & $7.8(8)$ & $24.6(25)$ & $12.8(13)$ & $11.8(12)$ & \\
\hline $\mathrm{E} 2(2-5 \mathrm{~cm})$ & 4 & $119(30)$ & $31.0 \pm 5.0$ & 102 & $17.6(18)$ & $32.4(33)$ & $16.2(16)$ & $16.2(16)$ & \\
\hline E00 (1-2 cm) & 12 & $240(20)$ & $20.9 \pm 2.2$ & 117 & $5.1(6)$ & $36.8(43)$ & $17.1(20)$ & $19.7(23)$ & 5 \\
\hline \multirow[t]{2}{*}{ E00 $(2-5 \mathrm{~cm})$} & 4 & $235(59)$ & $27.5 \pm 1.5$ & 100 & $3.0(3)$ & $49.0(49)$ & $25.0(25)$ & $24.0(24)$ & \\
\hline & & $\chi^{2}$ & F-test & $\chi^{2}$ & & & & & \\
\hline Genotype (A) & & $\mathrm{P} \leq 0.001$ & ns & Genotype (A) & & $\mathrm{P} \leq 0.01$ & ns & ns & \\
\hline Diameter (B) & & $\mathrm{P} \leq 0.001$ & $\mathrm{P} \leq 0.05$ & Diameter (B) & & $\mathrm{P} \leq 0.01$ & ns & ns & \\
\hline $\mathbf{A} \times \mathbf{B}$ & & $\mathrm{P} \leq 0.05$ & ns & $A \times B$ & & ns & ns & ns & \\
\hline
\end{tabular}

${ }^{\mathrm{I}}$ Evaluated after 4 weeks on growth chamber.

${ }^{2}$ Evaluated after 8 weeks of in vitro culture.

${ }^{3}$ The mean number of flushed shoot per branch is indicated in parenthesis.

${ }^{4}$ Average shoot length \pm standard deviation.

${ }^{5}$ Response rate is defined as the initial explants with sprounting buds after 8 weeks of in vitro culture.

${ }^{6}$ The actual numbers corresponding to the $\%$ are indicated in parenthesis.

${ }^{7}$ Cultures are considered stable when uniform and continuous growth is achieved in vitro.

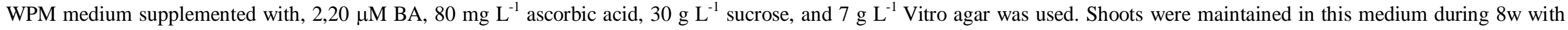

transferences each $2 \mathrm{w}$ and in the last $2 \mathrm{wk}$ BA was reduced to $0.89 \mu \mathrm{M}$.

The influenced of genotype on the sprouting responsiveness and the in vitro establishment was analyzed by chi-squared $\left(\chi^{2}\right)$ and two-way ANOVA. ns not significant. 
Table 2. Influence of STS $(20 \mu \mathrm{M})$ or $\mathrm{AgNO}_{3}(17.6 \mu \mathrm{M})$ in the culture medium on shoot multiplication of $Q$. ilex, genotype Q10.

\begin{tabular}{|c|c|c|c|c|c|}
\hline Treatment & $\begin{array}{l}\text { Proportion of } \\
\text { responsive } \\
\text { explants per } \\
\text { jar }(\%)^{2}\end{array}$ & $\begin{array}{c}\text { Average } \\
\text { number of } \\
\text { shoots } 0.5-1.0 \\
\text { cm in length } \\
\text { per jar }\end{array}$ & $\begin{array}{c}\text { Average } \\
\text { number of } \\
\text { shoots }<1 \mathrm{~cm} \\
\text { in length per } \\
\text { jar }\end{array}$ & $\begin{array}{c}\text { Average total } \\
\text { number } \\
\text { of shoots per } \\
\text { jar }\end{array}$ & $\begin{array}{l}\text { Mean longest } \\
\text { shoot } \\
\text { length per jar } \\
(\mathrm{mm})\end{array}$ \\
\hline Control $^{1}$ & $95.7 \pm 2.4 \mathrm{a}$ & $1.20 \pm 0.15 a$ & $0.9 \pm 0.05 a$ & $2.0 \pm 0.14 \mathrm{a}$ & $7.4 \pm 0.57 \mathrm{a}$ \\
\hline STS & $98.6 \pm 1.1 \mathrm{a}$ & $2.01 \pm 0.14 b$ & $1.94 \pm 0.14 b$ & $3.95 \pm 0.24 c$ & $13.0 \pm 0.43 b$ \\
\hline $\mathrm{AgNO}_{3}$ & $82.9 \pm 9.3 b$ & $1.34 \pm 0.26 \mathrm{a}$ & $1.37 \pm 0.37 \mathrm{a}$ & $2.71 \pm 0.53 b$ & $12.9 \pm 1.30 \mathrm{~b}$ \\
\hline
\end{tabular}

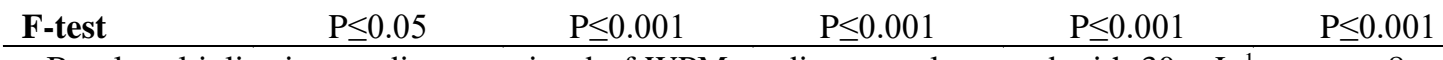

Basal multiplication medium consisted of WPM medium supplemented with $30 \mathrm{~g} \mathrm{~L}^{-1}$ sucrose, $8 \mathrm{~g} \mathrm{~L}^{-1}$ Sigma agar, and BA and Z, in accordance with 6 wk standard multiplication cycle. ${ }^{1}$ Control, basal multiplication medium without STS or $\mathrm{AgNO}_{3} .{ }^{2}$ Responsive explants defined as the percentage of explants forming shoots. In each treatment, data represent means \pm Standard Error (SE) of ten replicate jars with seven shoot explants per jar $(\mathrm{N}=70)$. Column means followed by different letters differ significantly at $P=0.05$ level, according to the least significant difference (LSD) or T3 Dunnett test. 
Table 3. Effect of basal medium on the shoot multiplication of Quercus ilex, genotype Q10.

\begin{tabular}{lccccc}
\hline $\begin{array}{l}\text { Basal } \\
\text { medium }\end{array}$ & $\begin{array}{c}\text { Proportion of } \\
\text { responsive } \\
\text { explants per } \\
\text { jar }(\mathbf{\%})^{\mathbf{1}}\end{array}$ & $\begin{array}{c}\text { Average number } \\
\text { of shoots } \mathbf{0 . 5 - 1 . 0} \\
\text { cm in length per } \\
\text { jar }\end{array}$ & $\begin{array}{c}\text { Average } \\
\text { Number of } \\
\text { shoots }>\mathbf{1 c m} \text { in } \\
\text { length per jar }\end{array}$ & $\begin{array}{c}\text { Average Total } \\
\text { number of } \\
\text { shoots per jar }\end{array}$ & $\begin{array}{c}\text { Mean longest } \\
\text { shoot length } \\
\text { per jar }(\mathbf{m m})\end{array}$ \\
\hline WPM & $100 \pm 0.0 \mathrm{a}$ & $1.70 \pm 0.19$ & $2.93 \pm 0.48 \mathrm{a}$ & $4.63 \pm 0.55 \mathrm{a}$ & $15.14 \pm 1.16 \mathrm{a}$ \\
GD & $100 \pm 0.0 \mathrm{a}$ & $1.64 \pm 0.20$ & $2.45 \pm 0.34 \mathrm{a}$ & $4.09 \pm 0.38 \mathrm{a}$ & $15.01 \pm 0.78 \mathrm{a}$ \\
SH & $88.9 \pm 9.0 \mathrm{~b}$ & $1.76 \pm 0.49$ & $1.33 \pm 0.63 \mathrm{a}$ & $3.09 \pm 0.90 \mathrm{ab}$ & $11.24 \pm 1.76 \mathrm{~b}$ \\
$\mathbf{1 / 2 M S}$ & $98.4 \pm 2.5 \mathrm{a}$ & $1.34 \pm 0.44$ & $1.05 \pm 0.25 \mathrm{~b}$ & $2.39 \pm 0.42 \mathrm{~b}$ & $11.96 \pm 1.01 \mathrm{~b}$ \\
F-test & $\mathrm{P} \leq 0.01$ & $\mathrm{~ns}$ & $\mathrm{P} \leq 0.001$ & $\mathrm{P} \leq 0.001$ & $\mathrm{P} \leq 0.01$
\end{tabular}

GD: Gresshoff and Doy (1972); 1/2 MS: half-strength macronutrients Murashige and Skoog (1962); SH: Schenk and Hildebrandt (1972); WPM: Lloyd and McCown (1981). All basal media were supplemented with $30 \mathrm{~g} \mathrm{~L}^{-1}$ sucrose, $8 \mathrm{~g} \mathrm{~L}^{-1}$ Sigma agar, $20 \mu \mathrm{M}$ STS, and BA and Z, in accordance with $6 \mathrm{wk}$ standard multiplication cycle. ${ }^{1}$ Responsive explants defined as the percentage of explants forming shoots. In each basal medium, data represent means \pm SE of ten replicate jars with seven shoot explants per jar $(\mathrm{N}=70)$. Column means followed by different letters differ significantly at $P=0.05$ level, according to the least significant difference (LSD) or T3 Dunnett test. ns, not significant. 
Table 4. Effect of sucrose concentration on the shoot multiplication of Quercus ilex, genotype Q10.

\begin{tabular}{lccccc}
\hline $\begin{array}{c}\text { Sucrose } \\
\text { concentration } \\
\left(\mathbf{g ~ L}^{-1}\right)\end{array}$ & $\begin{array}{c}\text { Proportion of } \\
\text { responsive } \\
\text { explants per } \\
\text { jar }(\%)^{\mathbf{1}}\end{array}$ & $\begin{array}{c}\text { Average } \\
\text { number of } \\
\text { shoots 0.5-1.0 } \\
\text { cm in length } \\
\text { per jar }\end{array}$ & $\begin{array}{c}\text { Average } \\
\text { number of } \\
\text { shoots }>\mathbf{1 c m} \\
\text { in length per } \\
\text { jar }\end{array}$ & $\begin{array}{c}\text { Average } \\
\text { Total } \\
\text { number of } \\
\text { shoots per jar }\end{array}$ & $\begin{array}{c}\text { Mean longest } \\
\text { shoot length } \\
\text { per jar }(\mathbf{m m})\end{array}$ \\
\hline $\mathbf{1 0}$ & $71.4 \pm 8.7 \mathrm{a}$ & $0.68 \pm 0.29 \mathrm{a}$ & $0.42 \pm 0.17 \mathrm{a}$ & $1.10 \pm 0.22 \mathrm{a}$ & $9.62 \pm 1.57 \mathrm{a}$ \\
$\mathbf{2 0}$ & $100 \pm 0.0 \mathrm{~b}$ & $2.08 \pm 0.35 \mathrm{~b}$ & $0.96 \pm 0.15 \mathrm{a}$ & $3.04 \pm 0.39 \mathrm{~b}$ & $10.76 \pm 1.07 \mathrm{a}$ \\
$\mathbf{3 0}$ & $100 \pm 0.0 \mathrm{~b}$ & $2.54 \pm 0.25 \mathrm{~b}$ & $2.30 \pm 0.27 \mathrm{~b}$ & $4.84 \pm 0.15 \mathrm{c}$ & $14.80 \pm 0.82 \mathrm{~b}$ \\
$\mathbf{F - t e s t}$ & $\mathrm{P} \leq 0.001$ & $\mathrm{P} \leq 0.001$ & $\mathrm{P} \leq 0.001$ & $\mathrm{P} \leq 0.001$ & $\mathrm{P} \leq 0.05$ \\
\hline
\end{tabular}

As basal multiplication medium, WPM medium supplemented $8 \mathrm{~g} \mathrm{~L}^{-1}$ Sigma agar, $20 \mu \mathrm{M}$ STS and BA and $\mathrm{Z}$, in accordance with 6 wk standard multiplication cycle was used. ${ }^{1}$ Responsive explants defined as the percentage of explants forming shoots. In each sucrose concentration, data represent means \pm SE of five replicate jars with seven shoot explants per jar $(\mathrm{N}=35)$. Column means followed by different letters differ significantly at $P=0.05$ level, according to the least significant difference (LSD) or T3 Dunnett test. 
Table 5. Effect of agar brand on shoot multiplication of Quercus ilex, genotype Q10.

\begin{tabular}{lccccc}
\hline Agar brand & $\begin{array}{c}\text { Proportion of } \\
\text { responsive } \\
\text { explants per } \\
\left.\text { jar } \mathbf{~ ( \% )})^{\mathbf{1}}\right)\end{array}$ & $\begin{array}{c}\text { Average number } \\
\text { of shoots } \mathbf{0 . 5 - 1 . 0} \\
\text { cm in length per } \\
\text { jar }\end{array}$ & $\begin{array}{c}\text { Average number of } \\
\text { shoots }>\mathbf{~} \mathbf{c m} \text { in } \\
\text { length per jar }\end{array}$ & $\begin{array}{c}\text { Average total } \\
\text { number of } \\
\text { shoots per jar }\end{array}$ & $\begin{array}{c}\text { Mean longest } \\
\text { shoot length per } \\
\text { jar }(\mathbf{m m})\end{array}$ \\
\hline Bacto & $100 \pm 0.0$ & $2.35 \pm 0.11 \mathrm{ab}$ & $1.61 \pm 0.19 \mathrm{a}$ & $3.96 \pm 0.17$ & $13.39 \pm 0.72$ \\
Vitro & $100 \pm 0.0$ & $2.88 \pm 0.23 \mathrm{~b}$ & $1.66 \pm 0.28 \mathrm{a}$ & $4.54 \pm 0.29$ & $13,35 \pm 0.91$ \\
Sigma & $100 \pm 0.0$ & $2.11 \pm 0.13 \mathrm{a}$ & $2.46 \pm 0.20 \mathrm{~b}$ & $4.57 \pm 0.17$ & $13.91 \pm 0.46$ \\
F-test & $\mathrm{ns}$ & $\mathrm{P} \leq 0.001$ & $\mathrm{P} \leq 0.05$ & $\mathrm{~ns}$ & $\mathrm{~ns}$
\end{tabular}

As basal multiplication medium, WPM medium supplemented with $30 \mathrm{~g} \mathrm{~L}^{-1}$ sucrose, $20 \mu \mathrm{M} \mathrm{STS}$, and BA and Z, in accordance with $6 \mathrm{wk}$ standard multiplication cycle was used. ${ }^{1}$ Responsive explants defined as the percentage of explants forming shoots. In each agar brand, data represent means \pm SE of ten replicate jars with seven shoot explants per jar ( $\mathrm{N}=70)$. Column means followed by different letters differ significantly at $P=0.05$ level, according to the least significant difference (LSD) or T3 Dunnett test. 
Table 6. Genotype influence on shoot multiplication of Quercus ilex explants.

\begin{tabular}{lccccc}
\hline Genotype & $\begin{array}{c}\text { Proportion of } \\
\text { responsive } \\
\text { explants per } \\
\text { jar }(\%)^{\mathbf{1}}\end{array}$ & $\begin{array}{c}\text { Average } \\
\text { number of } \\
\text { shoots } \mathbf{0 . 5}-\mathbf{1 . 0} \\
\mathbf{c m} \text { in length } \\
\text { per jar }\end{array}$ & $\begin{array}{c}\text { Average } \\
\text { number of } \\
\text { shoots }>\mathbf{1 c m} \text { in } \\
\text { length per jar }\end{array}$ & $\begin{array}{c}\text { Average Total } \\
\text { number of } \\
\text { shoots per jar }\end{array}$ & $\begin{array}{c}\text { Mean longest } \\
\text { shoot length } \\
\text { per jar }(\mathbf{m m})\end{array}$ \\
\hline Q3 & $100 \pm 0.0 \mathrm{~b}$ & $1.57 \pm 0.16$ & $1.15 \pm 0.18 \mathrm{a}$ & $2.72 \pm 0.30 \mathrm{~b}$ & $10.93 \pm 0.30 \mathrm{a}$ \\
Q6 & $65.9 \pm 6.7 \mathrm{a}$ & $1.31 \pm 0.30$ & $0.65 \pm 0.20 \mathrm{a}$ & $1.96 \pm 0.17 \mathrm{a}$ & $10.40 \pm 1.03 \mathrm{a}$ \\
Q10 & $98.6 \pm 1.4 \mathrm{~b}$ & $1.81 \pm 0.17$ & $2.41 \pm 0.20 \mathrm{~b}$ & $4.22 \pm 0.25 \mathrm{~d}$ & $14.49 \pm 0.30 \mathrm{~b}$ \\
E00 & $100 \pm 0.0 \mathrm{a}$ & $1.53 \pm 0.15$ & $1.92 \pm 0.17 \mathrm{~b}$ & $3.45 \pm 0.20 \mathrm{c}$ & $13.01 \pm 0.36 \mathrm{~b}$ \\
F-test & $\mathrm{P} \leq 0.001$ & $\mathrm{~ns}$ & $\mathrm{P} \leq 0.001$ & $\mathrm{P} \leq 0.001$ & $\mathrm{P} \leq 0.001$
\end{tabular}

As basal multiplication medium, WPM medium supplemented with $30 \mathrm{~g} \mathrm{~L}^{-1}$ sucrose, Sigma agar $0.8 \mathrm{~g}$ $\mathrm{L}^{-1}, 20 \mu \mathrm{M}$ STS, and BA and Z, in accordance with $6 \mathrm{wk}$ standard multiplication cycle was used. ${ }^{1}$ Responsive explants defined as the percentage of explants forming shoots. In each genotype, data represent means $\pm \mathrm{SE}$ of ten replicate jars with seven shoot explants per jar $(\mathrm{N}=70)$. 
ONLINE RESOURCE 1. Effect of cytokinin regime (cycles 1, 2, 3 and 4) on the in vitro shoot multiplication of Q. ilex, genotype Q10.

\begin{tabular}{l|c|c|c|c|c}
\hline $\begin{array}{l}\text { Cytokinin } \\
\text { regime }\end{array}$ & $\begin{array}{c}\text { Proportion of } \\
\text { responsive } \\
\text { explants per } \\
\text { jar }(\boldsymbol{\%})^{\mathbf{1}}\end{array}$ & $\begin{array}{c}\text { Average } \\
\text { number of } \\
\text { shoots } \mathbf{0 . 5}-\mathbf{1 . 0} \\
\text { cm in length } \\
\text { per jar }\end{array}$ & $\begin{array}{c}\text { Average number } \\
\text { of shoots }>\mathbf{1 c m} \\
\text { in length per jar }\end{array}$ & $\begin{array}{c}\text { Average } \\
\text { total } \\
\text { number of } \\
\text { shoots per } \\
\text { jar }\end{array}$ & $\begin{array}{c}\text { Mean longest } \\
\text { shootlength } \\
(\mathbf{m m}) \text { per jar }\end{array}$ \\
\hline Cycle 1 & $98.6 \pm 1.4 \mathrm{~b}$ & $1.9 \pm 0.2$ & $1.9 \pm 0.2 \mathrm{~b}$ & $3.9 \pm 0.3$ & $13.9 \pm 0.5$ \\
Cycle 2 & $94.3 \pm 2.3 \mathrm{a}$ & $1.5 \pm 0.2$ & $1.6 \pm 0.2 \mathrm{ab}$ & $3.1 \pm 0.3$ & $12.2 \pm 0.6$ \\
Cycle 3 & $100.0 \pm 0.0 \mathrm{~b}$ & $1.9 \pm 0.2$ & $1.7 \pm 0.2 \mathrm{~b}$ & $3.7 \pm 0.4$ & $12.9 \pm 1.0$ \\
Cycle 4 & $97.1 \pm 2.0 \mathrm{~b}$ & $1.9 \pm 0.2$ & $1.1 \pm 0.2 \mathrm{a}$ & $3.0 \pm 0.3$ & $11.9 \pm 0.9$ \\
F-test & $\mathrm{P}<0.05$ & $\mathrm{~ns}$ & $\mathrm{P}<0.05$ & $\mathrm{~ns}$ & $\mathrm{~ns}$ \\
\hline
\end{tabular}

Basal multiplication medium consisted of WPM medium supplemented with $30 \mathrm{~g} \mathrm{~L}^{-1}$ sucrose, and $8 \mathrm{~g} \mathrm{~L}^{-}$

${ }^{1}$ Sigma agar. This basal medium was supplemented with different cytokinin $(\mu \mathrm{M})$ combinations as follows:

Cycle 1: $0.44 \mathrm{BA}(2 \mathrm{wk}) \rightarrow 0.22 \mathrm{BA}(2 \mathrm{wk}) \rightarrow 0.04 \mathrm{BA}+0.46 \mathrm{Z}(2 \mathrm{wk})$

Cycle 2: $0.44 \mathrm{BA}+0.91 \mathrm{Z}(2 \mathrm{wk}) \rightarrow 0.22 \mathrm{BA}+0.46 \mathrm{Z}(2 \mathrm{wk}) \rightarrow 0.04 \mathrm{BA}+0.46 \mathrm{Z}(2 \mathrm{wk})$

Cycle 3: $2.28 \mathrm{Z}(2 \mathrm{wk}) \rightarrow 0.91 \mathrm{Z}(2 \mathrm{wk}) \rightarrow 0.46 \mathrm{Z}(2 \mathrm{wk})$

Cycle 4: $0.492 \mathrm{iP}+0.46 \mathrm{Z}(2 \mathrm{wk}) \rightarrow 0.242 \mathrm{iP}+0.46 \mathrm{Z}(2 \mathrm{wk}) \rightarrow 0.022 \mathrm{iP}+0.46 \mathrm{Z}(2 \mathrm{wk})$

In each cycle, data represent means $\pm \mathrm{SE}$ of ten replicate jars with seven shoot explants per jar $(\mathrm{N}=70)$. Column means followed by different letters differ significantly at $P=0.05$ level, according to the least significant difference (LSD) or T3 Dunnett test. 
ONLINE RESOURCE 2. Effect of explant type on the shoot proliferation of $Q$. ilex, genotype Q10.

\begin{tabular}{l|c|c|c|c|c}
\hline $\begin{array}{c}\text { Explant } \\
\text { type }\end{array}$ & $\begin{array}{c}\text { Proportion of } \\
\text { responsive } \\
\text { explants per jar } \\
(\%)^{\mathbf{1}}\end{array}$ & $\begin{array}{c}\text { Average } \\
\text { number of } \\
\text { shoots 0.5-1.0 } \\
\text { cm in length } \\
\text { per jar }\end{array}$ & $\begin{array}{c}\text { Average } \\
\text { number of } \\
\text { shoots }>\mathbf{1 c m} \\
\text { in length per } \\
\text { jar }\end{array}$ & $\begin{array}{c}\text { Average total } \\
\text { number of } \\
\text { shoots per jar }\end{array}$ & $\begin{array}{c}\text { Mean longest } \\
\text { shoot length } \\
\text { per jar (mm) }\end{array}$ \\
\hline Apex & $100 \pm 0.0$ & $1.70 \pm 0.14$ & $1.66 \pm 0.31$ & $3.36 \pm 0.38$ & $13.64 \pm 1.23$ \\
Node & $100 \pm 0.0$ & $1.89 \pm 0.31$ & $1.89 \pm 0.28$ & $3.81 \pm 0.40$ & $13.30 \pm 0.54$ \\
\hline
\end{tabular}

As basal multiplication medium, WPM medium supplemented $30 \mathrm{~g} \mathrm{~L}^{-1}$ sucrose, $8 \mathrm{~g} \mathrm{~L}^{-1}$ Sigma agar, $20 \mu \mathrm{M}$

STS and BA and Z, in accordance with $6 \mathrm{wk}$ standard multiplication cycle was used. ${ }^{1}$ Responsive explants

defined as the percentage of explants forming shoots. In each explant type, data represent means \pm SE of five replicate jars with seven shoot explants per jar $(\mathrm{N}=35)$. 
ONLINE RESOURCE 3. Influence of $14.8 \mu \mathrm{M}$ and $24.6 \mu \mathrm{M}$ IBA added into the rooting medium on rooting rates of clones $\mathrm{E} 00, \mathrm{Q} 3$ and $\mathrm{Q} 10$ of $Q$. ilex. In each auxin treatment, columns represent means \pm SE of 48 explants. The statistical analysis of these data is showed in the table.

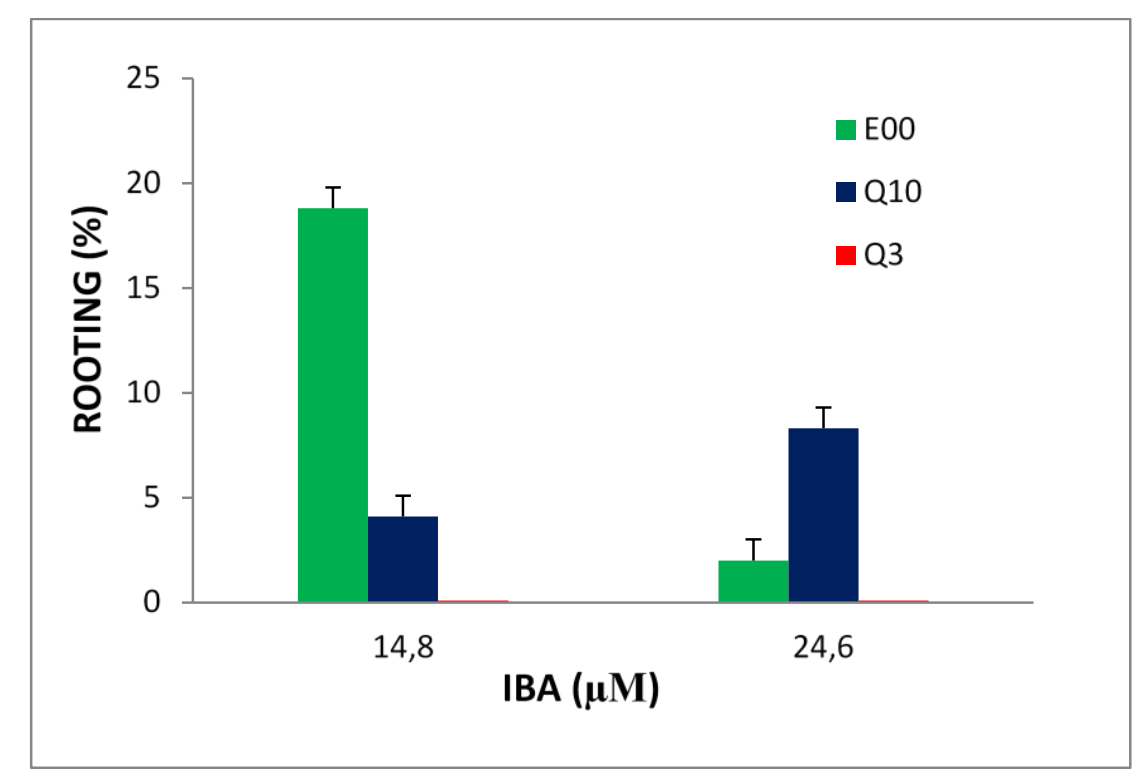

Table ONLINE RESOURCE 3. Contingency table analysis of the results showed in Figure. The effect of genotype and IBA concentration on rooting rates was analyzed by Chi square test.

\begin{tabular}{|l|c|c|c|c|}
\hline Source & $\begin{array}{c}\text { Number of } \\
\text { cultured } \\
\text { explants }\end{array}$ & DF & $\boldsymbol{\chi}^{\mathbf{2}}$ & $\boldsymbol{P}$-value \\
\hline IBA concentration & 288 & 1 & 0.303 & $\mathrm{~ns}$ \\
\hline Genotype & 288 & 2 & 10.059 & 0.007 \\
\hline
\end{tabular}

DF, free degrees; ns, not significant. 